\title{
Siklus hidup dan statistik demografi kutukebul Bemisia tabaci (Gennadius) (Hemiptera: Aleyrodidae) biotipe B dan non-B pada tanaman cabai (Capsicum annuum L.)
}

\author{
Life cycle and life table of the B and non-B biotypes of the whitefly \\ Bemisia tabaci (Gennadius) (Hemiptera: Aleyrodidae) on \\ chili pepper (Capsicum annuum L.)
}

\author{
Purnama Hidayat ${ }^{*}$, Hazen Arrazie Kurniawan ${ }^{1}$, Lutfi Afifah ${ }^{2}$, Hermanu Triwidodo ${ }^{1}$ \\ ${ }^{1}$ Departemen Proteksi Tanaman, Fakultas Pertanian, Institut Pertanian Bogor \\ Jalan Kamper, Kampus IPB Dramaga, Bogor 16680 \\ ${ }^{2}$ Program Studi Agroteknologi, Fakultas Pertanian, Universitas Singaperbangsa \\ Jalan H. S. RonggowaluyoTelukjambe Timur, Karawang 41361
}

(diterima April 2017, disetujui Juli 2017)

\begin{abstract}
ABSTRAK
Kutukebul Bemisia tabaci (Gennadius) biotipe B yang juga dikenal sebagai Bemisia argentifolii (Gennadius) merupakan jenis biotipe yang lebih ganas dalam merusak tanaman dibandingkan dengan biotipe non-B. Saat ini kutukebul B. tabaci biotipe B telah dilaporkan keberadaanya di Indonesia. Informasi dasar, seperti siklus hidup, lama hidup, keperidian, dan kemampuan berkembang biak kutukebul sangat diperlukan sebagai dasar dalam menyusun strategi pengendalian hama kutukebul tersebut. Penelitian bertujuan untuk mempelajari siklus hidup dan statistik demografi kutukebul B. tabaci biotipe B dan non-B pada tanaman cabai. Penelitian dilakukan dengan mengamati perkembangan sejak telur sampai menjadi dewasa di growth chamber yang terkontrol suhu dan pencahayaannya. Pengamatan dilakukan terhadap beberapa aspek biologi dan beberapa parameter statistik demografi. Hasil penelitian menunjukkan bahwa kutukebul $B$. tabaci biotipe B memiliki beberapa aspek biologi yang berbeda dengan non-B pada tanaman cabai. Siklus hidup kutukebul B. tabaci biotipe $\mathrm{B}$ dan non-B masing-masing adalah 33,27 dan 30,86 hari. Kutukebul B. tabaci biotipe $B$ memiliki laju reproduksi bersih $\left(\mathrm{R}_{0}\right)$ yang hampir sama dengan biotipe non-B, begitu juga rataan masa generasinya. Namun demikian, laju pertambahan intrinsik (r) kutukebul B. tabaci biotipe B 2,5 kali lebih cepat dibandingkan biotipe non-B. Kutukebul B. tabaci biotipe B berlipat ganda populasinya (DT) 2 kali lebih cepat dibandingkan biotipe non-B. Kutukebul B. tabaci biotipe $\mathrm{B}$ berpotensi lebih berbahaya dibandingkan dengan biotipe non-B sehingga perlu diwaspadai keberadaannya.
\end{abstract}

Kata kunci: siklus hidup, statistik demografi, pertambuhan intrinsik, reproduksi

\begin{abstract}
The whitefly Bemisia tabaci (Gennadius) biotype B also known as Bemisia argentifolii (Gennadius) is a more malignant whitefly biotype in damaging plants compared to non-B biotype. Currently the whitefly B. tabaci biotype B has been reported to exist in Indonesia. Basic information such as life cycle, length of life, fecundity, and breeding ability of a whitefly is important information as a basis in preparing the whitefly control strategy. The aim of this research was to study the life cycle and demographic statistic of the B. tabaci biotype B and the non-B biotype on chili pepper. The study was conducted by observing the development of the whiteflies from eggs to
\end{abstract}


adult in a growth chamber that the temperature and lighting were controlled. Observations were made on several aspects of biology and some parameters of demographic statistics. The results showed that the biotype B of $B$. tabaci has several different biological aspects with the non-B whitefly in chili pepper. The life cycle of the biotype B of $B$. tabaci and the non-B were different, 33.27 and 30.86 days respectively. The biotype $\mathrm{B}$ of $\mathrm{B}$. tabaci had a net reproduction rate $\left(\mathrm{R}_{0}\right)$ which was similar to that of the non-B biotype as well as the average of its generation. However, the intrinsic increase rate (r) of the biotype B $B$. tabaci was 2.5 times shorter than the non-B biotype. The biotype $\mathrm{B}$ of $B$. tabaci doubled its population (DT) 2 times faster than the non-B biotype. It is clear that the biotype B of B. tabaci potentially more dangerous than the non-B.

Key words: demographic statistics, intrinsic rate, life table, reproduction rate

\section{PENDAHULUAN}

Bemisia tabaci (Gennadius) (Hemiptera: Aleyrodidae) adalah kutukebul yang umum ditemukan pada tanaman tembakau dan sudah dikenal lebih dari 100 tahun yang lalu sebagai hama yang merugikan pada berbagai tanaman di daerah tropik maupun subtropik (Oliveira et al. 2001). Serangga ini dapat menimbulkan kerusakan langsung pada tanaman dengan menghisap cairan makanan (van de Ven et al. 2000), menimbulkan gangguan fisiologis (McCollum et al. 2004), dan memacu tumbuhnya cendawan embun jelaga pada tanaman inangnya. Kutukebul B. tabaci diketahui dapat berperan sebagai vektor berbagai virus yang dapat menyebabkan penyakit pada tanaman (Legg et al. 2002).

Kutukebul B. tabaci di Indonesia diketahui pertama kali pada tahun 1938 sebagai penyebab penyakit kerupuk di tanaman tembakau di daerah Sumatra dan Jawa, yang ditularkan dari gulma Ageratum sp., Synedrella sp., dan Eupatorium odoratum (Kalshoven \& Vecht 1950). Penyebab penyakit ini, yaitu virus yang termasuk ke dalam Geminivirus. Infeksi virus ini ditakuti oleh petani karena menyebabkan tanaman menjadi kerdil dan tidak berbuah. Beberapa tanaman yang terserang Geminivirus, seperti African cassava mosaic Geminivirus (ACMV) dapat menginfeksi tanaman ubi kayu di Afrika dan Ageratum yellow vein virus (AYVV) dapat menginfeksi tanaman babadotan (Harris et al. 2001).

Kutukebul B. tabaci diketahui pada tahun 1986 di Florida, pada tanaman Euphorbia pulcherrima Willdenow menimbulkan gejala keperakan. Hingga saat ini fenomena timbulnya biotipe pada $B$. tabaci menjadi masalah di beberapa negara, seperti di Amerika pada tanaman kapas, Afrika pada tanaman ubi kayu, dan di Indonesia pada tanaman cabai dan tomat (Flint et al. 1990; Harris et al. 2001; Sudiono 2003; Hidayat et al. 2008). Penentuan biotipe B juga didasarkan pada kemampuan berkembangbiak $B$. tabaci yang tinggi, daya tahan terhadap beberapa insektisida (Horowitz et al. 1998; Bellotti \& Arias 2001), dan kemampuan penularan virus yang berbeda antar biotipe $B$. tabaci (Aidawati 2006). Bellows et al. (1994) memisahkan Bemisia argentifolii (Gennadius) sebagai spesies baru yang berbeda dengan $B$. tabaci berdasarkan perilaku, karakter morfologi, dan molekuler. Namun de Barro et al. (2005) menyatakan bahwa $B$. argentifolii merupakan kutukebul B. tabaci biotipe B. Kutukebul B. tabaci biotipe B telah diuji dan dilaporkan keberadaanya di Bogor pada tahun 2008 (Hidayat et al. 2008). Menurut Costa \& Brown (1991) perbedaan biologi antara $B$. tabaci biotipe $\mathrm{B}$ dan biotipe A terlihat dari tingkat keperidiannya, tanaman inang yang luas, dan ketahanan pada beberapa insektisida yang lebih baik pada $B$. tabaci biotipe B serta kemampuannya dalam menimbulkan gejala keperakan. Hasil survei yang dilakukan oleh Lima et al. (2000) di Brazil pada 57 lokasi dengan 27 tanaman yang berbeda diperoleh fakta bahwa B. tabaci biotipe B lebih dominan dijumpai daripada biotipe $\mathrm{A}$.

Di Indonesia informasi mengenai biologi B. tabaci biotipe $\mathrm{B}$ masih terbatas. Penelitian mengenai statistik demografi B. tabaci biotipe B dan non-B pada tanaman cabai penting dilakukan untuk mengetahui resiko kerusakan tanaman cabai. Penelitian ini bertujuan untuk mempelajari siklus hidup dan statistik demografi kutukebul $B$. tabaci (Hemiptera: Aleyrodidae) biotipe B dan non-B pada tanaman cabai (Capsicum annuum $\mathrm{L}$.) dengan parameter statistik demografi. 


\section{BAHAN DAN METODE}

\section{Perbanyakan serangga uji}

Perbanyakan serangga uji dan perbanyakan tanaman uji dilakukan di rumah kaca di Kebun Percobaan Institut Pertanian Bogor (IPB), Cikabayan, Dramaga, Bogor. Serangga uji B. tabaci biotipe B berasal dari tanaman brokoli (Brassica oleraceae var. Sakata), sedangkan B. tabaci non-B berasal dari tanaman terung (Solanum melongena L.) di Bogor. Perbanyakan kedua biotipe tersebut dilakukan di rumah kaca Departemen Proteksi Tanaman di Cikabayan. B. tabaci biotipe B dipelihara pada tanaman brokoli, sedangkan $B$. tabaci non-B dipelihara pada tanaman tembakau (Nicotiana tabacum L.) di dalam sebuah kurungan kasa yang berbeda. Tanaman uji yang digunakan adalah cabai (Capsicum annuum L.) var TM888. Penelitian dilaksanakan di Laboratorium Biotaksonomi Serangga, Departemen Proteksi Tanaman, Fakultas Pertanian, IPB.

\section{Persiapan dan pengamatan percobaan siklus hidup dan statistik demografi}

Informasi tentang siklus hidup, kemampuan hidup, lama hidup, dan laju pertumbuhan populasi didapatkan dari parameter statistik demografi (life table). Untuk memperoleh telur B. tabaci biotipe $B$ dan non-B pada tanaman cabai kutukebul dipelihara di dalam plastik mika berbentuk tabung silinder (tinggi $25 \mathrm{~cm}$, diameter $8 \mathrm{~cm}$ ) dan pada bagian atasnya dilapisi kain kasa. Pada bagian tengah plastik mika terdapat lubang yang berfungsi untuk memasukkan imago $B$. tabaci. Setelah itu, ke dalam tabung plastik dimasukkan lima pasang B. tabaci. Tahap awal pengujian dan pengamatan dimulai dari fase telur, nimfa, pupa, dan imago. Telur yang digunakan untuk pengujian adalah sebanyak 100 telur dan diamati setiap hari dengan bantuan mikroskop binokuler. Pengujian di laboratorium dilakukan dengan menggunakan
B. tabaci biotipe B dan non-B generasi kedua dari masing-masing tanaman cabai uji.

\section{Parameter dan analisis statistik demografi}

Parameter statistik demografi digunakan untuk melihat hubungan preferensi kutukebul terhadap tanaman yang diujikan. Statistik demografi serangga oleh Zeng et al. (1993) diartikan sebagai analisis secara kuantitatif populasi serangga hama dalam hubungannya dengan kelangsungan hidup, keperidian, dan pola pertumbuhan populasi. Data mengenai daya kemampuan hidup dan keperidian disusun dalam bentuk statistik demografi (life table). Parameter demografi yang dihitung menurut Birch (1948) (Tabel 1).

Peubah biologi yang diamati meliputi: 1) lama waktu perkembangan sejak telur di letakkan oleh imago hingga menetas menjadi nimfa instar satu; 2) lama waktu perkembangan nimfa instar satu hingga instar empat; 3) lama waktu perkembangan nimfa instar empat hingga menjadi pupa; 4) lama waktu perkembangan pupa hingga menjadi imago; 5) lama hidup imago sejak keluar dari pupa sampai mati; 6) masa sebelum peletakkan telur hingga meletakkan telur; dan 7) jumlah telur yang diletakkan. Siklus hidup, lama hidup, dan keperidian Bemisia tabaci Biotipe B dan non-B pada tanaman cabai dianalisis secara statistik menggunakan uji t ( $\alpha=5 \%)$ dengan program SAS 9.1 .

\section{HASIL}

\section{Siklus hidup B. tabaci biotipe B dan non-B pada tanaman cabai}

Hasil pengamatan harian menunjukkan bahwa siklus hidup B. tabaci biotipe B dan non-B pada tanaman cabai berturut-turut adalah 33,27 hari dan 30,86 hari (Tabel 2). Siklus hidup adalah selang waktu sejak telur diletakkan hingga saat imago

Tabel 1. Parameter demografi yang dihitung

\begin{tabular}{ll}
\hline Parameter & Rumus \\
\hline Laju reproduksi bersih $\left(\mathrm{R}_{0}\right)$ & $\mathrm{R}_{0}=\sum 1_{\mathrm{X}} \mathrm{m}_{\mathrm{X}}$ \\
Laju reproduksi kotor (GRR) & $\mathrm{GRR}=\sum \mathrm{m}_{\mathrm{X}}$ \\
Laju pertambahan intrinsik (r) & $\sum \mathrm{l}_{\mathrm{X}} \mathrm{m}_{\mathrm{X}} \mathrm{e}^{-\mathrm{TX}}=1$ \\
Rataan masa generasi (T) & $\mathrm{T}=\sum \mathrm{x} \mathrm{l}_{\mathrm{X}} \mathrm{m}_{\mathrm{X}} / \sum \mathrm{l}_{\mathrm{X}} \mathrm{m}_{\mathrm{X}}$ \\
Populasi berlipat ganda (DT) & $\mathrm{DT}=\ln (2) / \mathrm{r}$ \\
\hline
\end{tabular}

$\mathrm{X}$ : kelas umur kohor (hari); $1_{\mathrm{X}}$ : proporsi individu yang hidup pada umur $\mathrm{x} ; \mathrm{m}_{\mathrm{X}}$ : keperidian spesifik individu-individu pada kelas umur $\mathrm{x}$ atau jumlah. Anak betina perkapita yang lahir pada kelas $\mathrm{x}$. 
betina meletakkan telur untuk pertama kalinya. Imago betina $B$. tabaci biotipe B mulai meletakkan telur pada hari ke-27, dengan masa peneluran 15,58 hari, dan jumlah telur yang diletakkan 82,05 butir per betina. Sementara itu, imago betina $B$. tabaci biotipe non-B meletakkan telur sebanyak 94,41 butir per betina dengan masa peneluran 14,75 hari (Tabel 2).

Perbandingan nisbah kelamin (sex ratio) antara B. tabaci biotipe $\mathrm{B}$ dan non-B pada tanaman cabai adalah $1: 2$ (jantan : betina), artinya kedua biotipe B. tabaci lebih banyak menghasilkan keturunan betina daripada jantan. Secara umum, lama hidup imago betina pada dua biotipe tersebut hampir sama (Tabel 2). Mortalitas B. tabaci biotipe B tertinggi pada tanaman cabai terjadi pada fase telur sebesar $30 \%$ dan nimfa instar satu sebesar $15,71 \%$. Sementara itu, mortalitas tertinggi $B$. tabaci non-B terjadi pada fase telur adalah $25 \%$ dan nimfa instar satu sebesar 16\% (Tabel 3). Hasil uraian di atas menunjukkan bahwa mortalitas kedua biotipe $B$. tabaci tertinggi terjadi pada fase pradewasa.

Lama hidup kutukebul B. tabaci botipe B dan non-B pada tanaman cabai hampir sama, yaitu berturut-turut 54 hari dan 53 hari. Banyaknya telur yang diletakkan setiap harinya disajikan dalam Tabel 3, Gambar 1A dan 1B. Nilai $m_{X}$ dan puncak kurva $B$. tabaci biotipe $\mathrm{B}$ dan non-B berturut-turut adalah 49,36 pada hari ke-31-50 dan 38,67 pada hari ke-29-44 (Gambar 1A dan 1B).

Tipe bertahan hidup B. tabaci biotipe B dan non-B memperlihatkan pola yang dikenal dengan tipe II (Gambar 1A dan 1B). Laju kematian pada kedua biotipe terlihat konstan. Hal tersebut ditunjukkan dengan kematian pada awal dan akhir perkembangan B. tabaci rendah.

\section{Statistik demografi $B$. tabaci biotipe B dan non-B pada tanaman cabai}

Parameter statistik demografi $B$. tabaci biotipe $\mathrm{B}$ dan non-B pada tanaman cabai mencakup $\mathrm{R}_{0}, \mathrm{r}$, T, dan DT (Tabel 4). Nilai laju reproduksi bersih $\left(\mathrm{R}_{0}\right)$ B. tabaci biotipe B dan non-B pada tanaman cabai menunjukkan bahwa banyaknya keturunan betina yang dihasilkan oleh induk imago betina dalam setiap generasi pada kedua biotipe hampir sama, yaitu 15,30 per individu pada biotipe B dan 15,41 per individu pada biotipe non-B. Namun demikian, laju pertambahan intrinsik (r) B. tabaci biotipe B 2,5 kali lebih cepat dibandingkan dengan biotipe non-B, yaitu masing-masing 0,17 dan 0,07 individu/induk/hari.

Rataan masa generasi ( $\mathrm{T}$ ) adalah rataan waktu yang dibutuhkan sejak telur diletakkan hingga saat imago betina menghasilkan separuh

Tabel 2. Siklus hidup, lama hidup, dan keperidian Bemisia tabaci biotipe B dan non-B pada tanaman cabai

\begin{tabular}{lcc}
\hline Parameter populasi & B. tabaci biotipe B & B. tabaci non-B \\
\hline Siklus hidup (hari) \pm SD & $33,27 \pm 1,54 \mathrm{a}$ & $30,86 \pm 1,57 \mathrm{~b}$ \\
Lama hidup imago betina (hari) \pm SD & $20,70 \pm 4,61 \mathrm{a}$ & $20,94 \pm 4,32 \mathrm{a}$ \\
Keperidian (butir telur) \pm SD & $94,41 \pm 25,54 \mathrm{a}$ & $82,05 \pm 22,57 \mathrm{~b}$ \\
\hline
\end{tabular}

Angka-angka pada kolom yang sama pada biotipe berbeda serta diikuti oleh huruf yang sama menunjukkan hasil yang tidak berbeda nyata berdasarkan uji t pada taraf $\alpha=5 \%$; SD $=$ standar deviasi.

Tabel 3. Kemampuan lama hidup $\left(\mathrm{l}_{\mathrm{X}}\right)$ dan keperidian $\left(\mathrm{m}_{\mathrm{X}}\right)$ Bemisia tabaci biotipe-B dan non-B pada tanaman cabai

\begin{tabular}{|c|c|c|c|c|c|c|c|c|}
\hline \multirow{2}{*}{ Stadia } & \multicolumn{4}{|c|}{ Biotipe-B } & \multicolumn{4}{|c|}{ Biotipe non-B } \\
\hline & $\mathrm{n}$ & hari & $1_{\mathrm{X}}$ & $m_{X}$ & $\mathrm{n}$ & hari & $1_{\mathrm{X}}$ & $m_{X}$ \\
\hline Telur & 100 & $0-8$ & 1 & - & 100 & $0-7$ & 1 & - \\
\hline Instar-1 & 70 & $9-14$ & 0,70 & - & 75 & $8-12$ & 0,75 & - \\
\hline Instar-2 & 59 & $15-18$ & 0,59 & - & 62 & $13-17$ & 0,62 & - \\
\hline Instar-3 & 53 & $19-22$ & 0,53 & - & 62 & $18-20$ & 0,62 & - \\
\hline Instar-4 & 53 & $23-26$ & 0,53 & - & 62 & $21-24$ & 0,62 & - \\
\hline Pupa & 53 & $27-30$ & 0,53 & - & 62 & $25-28$ & 0,62 & - \\
\hline Imago & 36 & $31-50$ & 0,36 & 49,36 & 42 & $29-44$ & 0,42 & 38,67 \\
\hline
\end{tabular}

$\mathrm{l}_{\mathrm{X}}$ : individu yang hidup pada umur ke-x; $\mathrm{m}_{\mathrm{X}}$ : keperidian individu pada umur ke-x. 
keturunannya. Berdasarkan hasil pengujian, dibutuhkan B. tabaci biotipe B dalam berlipat terlihat bahwa waktu yang dibutuhkan B. tabaci ganda (DT) 2 kali lebih cepat dibandingkan biotipe $\mathrm{B}$ hampir sama dengan biotipe non-B, dengan $B$. tabaci non-B, yaitu masing-masing dengan nilai $T$ yang diperoleh masing-masing dalam waktu 3,96 hari dan 9,21 hari (Tabel 4). adalah 37,69 dan 37,14 hari. Namun, waktu yang
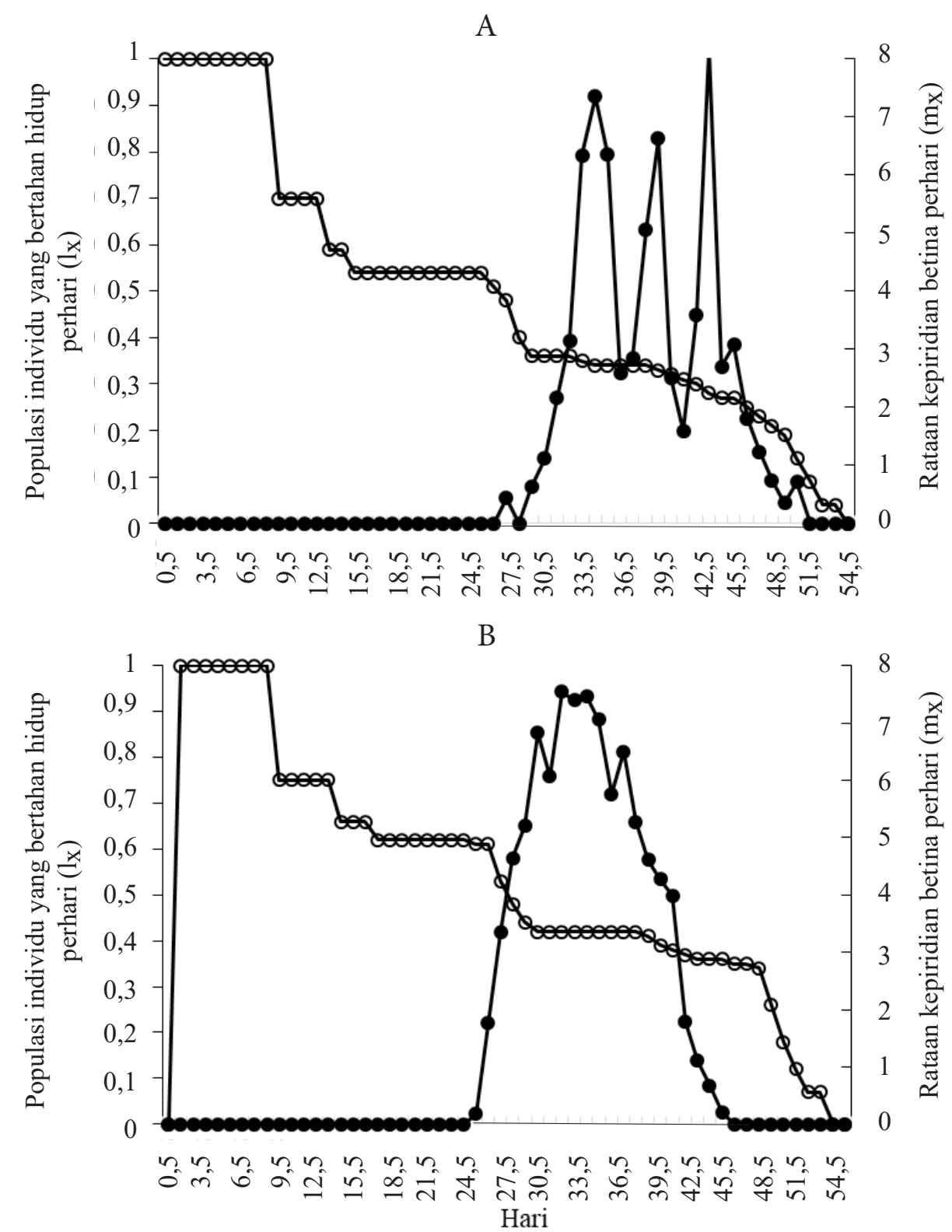

Gambar 1. Kurva lama hidup $\left(1_{\mathrm{X}}:-\hookrightarrow\right)$ dan rataan keperidian betina per hari ( $\left.\mathrm{m}_{\mathrm{X}}:-\boldsymbol{\bullet}\right)$. A: Bemisia tabaci biotipe B; dan B: biotipe non-B pada tanaman cabai.

Tabel 4. Statistik demografi Bemisia tabaci biotipe B dan non-B pada tanaman cabai

\begin{tabular}{lccc}
\hline Parameter populasi & Biotipe B & Biotipe non-B & Keterangan \\
\hline $\mathrm{R}_{0}$ & 15,30 & 15,41 & Individu/induk/generasi \\
$\mathrm{r}$ & 0,17 & 0,07 & Individu/induk/hari \\
$\mathrm{T}$ & 37,69 & 37,14 & Hari \\
$\mathrm{DT}$ & 3,96 & 9,21 & Hari \\
\hline
\end{tabular}

$\mathrm{R}_{0}$ : laju reproduksi bersih; r: laju pertambahan intrinsik; T: rataan masa generasi; DT: populasi berlipat ganda. 


\section{PEMBAHASAN}

Siklus hidup B. tabaci pada biotipe B dan non-B di tanaman cabai memiliki kisaran waktu yang dibutuhkan dari telur hingga dewasa berturut-turut adalah $33,27 \pm 1,54$ hari dan $30,86 \pm 1,57$ hari. Hal tersebut menunjukkan bahwa siklus hidup $B$. tabaci biotipe non-B lebih singkat dibandingkan dengan B. tabaci biotipe B. Perbedaan siklus hidup ini dipengaruhi oleh kemampuan imago bertahan hidup pada tanaman cabai, imago $B$. tabaci biotipe $\mathrm{B}$ memiliki kemampuan bertahan hidup yang lebih lama dibandingkan dengan B. tabaci non-B. Keadaan ini dapat disebabkan oleh kebutuhan makan, perilaku seekor serangga, dan jenis makanannya, yang selanjutnya akan menentukan keperidian dan strategi reproduksinya (Awmack \& Leather 2002). Menurut Naranjo \& Ellsworth (2005), tanaman inang merupakan salah satu faktor biotik yang dapat memengaruhi aspek biologi dan kelangsungan hidup suatu organisme. Siklus hidup dua biotipe tersebut lebih lama dibandingkan dengan laporan Chintkuntlawar et al. (2016) yang menyatakan bahwa siklus hidup B. tabaci pada tanaman cabai suhu $24-31^{\circ} \mathrm{C}$ dan kelembaban $80-85 \%$, berkisar antara 20-23 hari. Faktor lainnya yang juga memengaruhi siklus hidup B. tabaci adalah suhu (Wang \& Tsai 1996; Subagyo et al. 2014).

Imago betina mulai meletakkan telur di permukaan daun setelah terjadinya kopulasi dengan imago jantan. Jumlah telur yang diletakkan oleh imago betina $B$. tabaci biotipe $\mathrm{B}$ dan non-B pada tanaman cabai, yaitu sebanyak 94,41 butir dan 82,05 butir (Tabel 2). Adapun perbedaan jumlah telur yang dihasilkan oleh betina $B$. tabaci diduga karena adanya faktor fisik dan kimia tanaman. Menurut Harris et al. (2001) kemampuan imago betina $B$. tabaci dalam menghasilkan telur dan siklus hidupnya dipengaruhi oleh jenis tanaman inang dan kondisi suhu. Perbandingan sex rasio antara B. tabaci biotipe B dan non-B pada tanaman cabai adalah $1: 2$ (satu jantan banding dua betina). B. tabaci bersifat arrhenotokous artinya lebih banyak menghasilkan betina daripada jantan. Dengan demikian, jumlah individu betina dapat memengaruhi nilai keperidian. Jumlah imago betina yang lebih banyak daripada imago jantan dapat menimbulkan masalah jika serangga tersebut menimbulkan kerugian. Hal ini disebabkan oleh perkembangan populasi di suatu habitat ditentukan oleh banyaknya imago betina, artinya semakin banyak imago betina maka populasi akan semakin meningkat.

Tipe bertahan hidup B. tabaci biotipe B dan non-B adalah tipe II. Menurut Price (1984) terdapat tiga jenis kurva bertahan hidup serangga di alam, yaitu tipe I, II, dan III. Kurva tipe I menggambarkan kematian yang rendah pada awal perkembangan organisme kemudian meningkat secara perlahan seiring pertambahan umur, tipe II menggambarkan laju kematian yang konstan, dan tipe III menggambarkan kematian yang tinggi pada awal perkembangan organisme kemudian menurun secara perlahan seiring pertambahan umur.

Laju reproduksi bersih $\left(\mathrm{R}_{0}\right)$ menunjukkan banyaknya keturunan betina yang dihasilkan oleh induk imago betina dalam setiap generasi. Sementara itu, nilai rataan masa generasi (T) diartikan sebagai rataan waktu yang dibutuhkan sejak telur diletakkan hingga saat imago menghasilkan keturunan. B. tabaci biotipe B dan non-B pada tanaman cabai terlihat memiliki nilai $\mathrm{R}_{0}$ dan $\mathrm{T}$ yang hampir sama (Tabel 4). Pada $B$. tabaci biotipe $\mathrm{B}$ diperoleh nilai laju reproduksi bersihnya $\left(\mathrm{R}_{0}\right)$ dan nilai laju reproduksi kotornya (GRR) masing-masing 15,30 per induk per generasi dan 49,36 per betina, dengan nilai rataan masa generasinya 37 hari. Nilai tersebut diartikan sebagai bentuk respons dari nilai rataan masa generasi yang pendek, yang menyebabkan imago betina meningkatkan nilai $\mathrm{R}_{0}$ dan GRR. Menurut Oka (1995), jika kedua populasi dari spesies yang berbeda mempunyai nilai $R_{0}$ yang sama, tetapi salah satu spesies mempunyai nilai $\mathrm{T}$ yang rendah, sedangkan yang kedua mempunyai nilai $\mathrm{T}$ yang tinggi maka nilai laju pertambahan intrinsik dalam satuan waktu tertentu akan berbeda. Spesies populasi yang mempunyai nilai $\mathrm{T}$ yang rendah akan tumbuh dan berkembang biak lebih cepat dibandingkan dengan spesies yang mempunyai nilai $\mathrm{T}$ yang tinggi.

Waktu yang dibutuhkan untuk populasi berlipat ganda (DT) pada B. tabaci biotipe B 2 kali lebih cepat dibandingkan dengan $B$. tabaci biotipe non-B, yaitu masing-masing dalam waktu 3,96 hari dan 9,21 hari. Nilai DT yang tinggi 
tersebut dapat menyebabkan meningkatnya GRR dan nilai $\mathrm{R}_{0}$ dalam satuan waktu tertentu. Menurut Birch (1948), nilai berlipat populasi ganda yang tinggi pada suatu individu dapat menyebabkan penurunan sumber-sumber daya lingkungan dan memengaruhi pada nilai laju pertambahan intrinsik (r).

Laju pertambahan intrinsik (r) merupakan kapasitas suatu populasi mengalami peningkatan, nilai yang diperoleh ditentukan oleh berbagai aspek yang berhubungan dengan sejarah kehidupan organisme, yaitu kematian, kelahiran, dan waktu perkembangan. Pada tanaman cabai, nilai $\mathrm{r}$ B. tabaci biotipe B 2,5 kali lebih tinggi dibandingkan dengan biotipe non-B, yaitu masing-masing 0,17 dan 0,07 individu/induk/ hari. Suatu populasi akan mencapai nilai laju pertambahan intrinsik yang tinggi apabila suatu individu mencapai dewasa dengan reproduksi yang awal. Menurut Birch (1948), jika nilai $r$ lebih kecil dari nilai laju pertambahan intrinsik yang minimum maka spesies tersebut gagal dalam bertahan hidup. Namun, nilai laju pertambahan intrinsik yang tinggi pada suatu spesies tidak selalu diartikan sebagai tingkat keberhasilan dalam suatu habitat. Hal tersebut berdasarkan adanya proses seleksi dari spesies tersebut agar nilai r-nya menjadi relatif tinggi untuk mampu berkompetisi dengan spesies yang lain. Hasil laporan Ginting (1996), menunjukkan bahwa perbedaan nilai $\mathrm{r}$ antara kohort bunga dan kohort polong pada tanaman kacang panjang disebabkan oleh adanya perbedaan nilai $\mathrm{m}_{\mathrm{X}}$, sedangkan pada nilai $\mathrm{l}_{\mathrm{X}}$ dan T tidak banyak berbeda. Brewer (1979) membagi dalam empat faktor yang menyebabkan tinggi dan rendahnya nilai laju pertambahan intrinsik, yaitu jumlah keturunan per periode perkembangan, jumlah yang bertahan hidup dan selama masa reproduktif, usia saat reproduktif dimulai, dan lama usia reproduktif. Dari nilai statistik demografi yang diperoleh dapat diketahui bahwa B. tabaci biotipe B pada tanaman cabai mampu berkembang biak 2 kali lebih cepat serta memiliki laju pertumbuhan yang cepat dibandingkan dengan $B$. tabaci non-B. Perbedaan biotipe pada kutukebul B. tabaci dapat menunjukkan perbedaan yang jelas pada kemampuan menghasilkan keturunan. Hal ini berkaitan dengan perbedaan susunan genetik kedua biotipe, strategi, dan perilaku dalam bertahan hidup pada tanaman inangnya. Zang \& Liu (2007) melaporkan bahwa B. tabaci biotipe B memiliki perilaku kawin dengan frekuensi yang lebih tinggi serta kecenderungan untuk kawin yang lebih kuat. Biotipe B. tabaci yang berbeda memiliki kemampuan beradaptasi pada inang yang berhubungan dengan kelangsungan hidup dan reproduksi (Zang et al. 2006), kemampuan resistensi terhadap pestisida serta mentransmisikan Geminivirus (Qiu B et al. 2009). B. tabaci biotipe $\mathrm{B}$ diketahui memiliki potensi invasi yang membahayakan dibandingkan dengan biotipe non-B (Zang \& Liu 2007).

\section{KESIMPULAN}

Siklus hidup kutukebul B. tabaci biotipe B lebih panjang dua hari dibandingkan dengan biotipe non-B. Kutukebul B. tabaci biotipe B memiliki laju pertambahan intrinsik 2,5 kali lebih cepat dibandingkan dengan $B$. tabaci non-B. Selain itu, kutukebul B. tabaci biotipe B juga memiliki kemampuan belipat ganda populasinya 2 kali lebih cepat dibandingkan dengan B. tabaci non-B. Beberapa hal tersebut di atas mengindikasikan bahwa kutukebul B. tabaci biotipe B memiliki potensi menyebabkan kerusakan lebih besar pada tanaman cabai dibandingkan dengan biotipe non-B, oleh karena itu keberadaanya perlu diwaspadai.

\section{DAFTAR PUSTAKA}

Aidawati N. 2006. Keanekaragaman Begomovirus pada tomat dan serangga vektornya, Bemisia tabaci gennadius (Hemiptera: aleyrodidae), serta pengujian ketahanan genotipe tomat terhadap strain Begomovirus. Disertasi. Bogor: Institut Pertanian Bogor.

Awmack CS, Leather SR. 2002. Host plant quality and fecundity in herbivorous insects. Annual Review of Entomology 47:817-844. doi: https://doi. org/10.1146/annurev.ento.47.091201.145300.

Bellotti AC, Arias B. 2001. Host plant resistance to whiteflies with emphasis on cassava as a case study. Crop Protection 20:813-823. doi: https:// doi.org/10.1016/S0261-2194(01)00113-2.

Bellows TS Jr, Perring TM, Gill RJ, Headrick DH. 1994. Description of a species of Bemisia (Homoptera: Aleyrodidae). Annals of The 
Entomological Society of America 87:195-206. doi: https://doi.org/10.1093/aesa/87.2.195.

Birch LC. 1948. The intrinsic rate of natural increase of an insect population. The Journal of Animal Ecology 17:15-26. doi: https://doi. org/10.2307/1605.

Brewer R. 1979. Principles of ecology. Phidelphia: W.B Sounders Co.

Chintkuntlawar PS, Pramanik A, Chatterjee H. 2016. Biology and physical measurements of whitefly, Bemisia tabaci (Gennadius) on chilli in West Bengal, India. International Journal of Agricultural Science 8:2063-2065.

Costa H, Brown JK. 1991. Variation in biological characteristics and esterase patterns among populations of Bemisia tabaci, and the association of one population with silverleaf symptom induction. Entomologia Experimentalis et Applicata 61:211-219. doi: https://doi. org/10.1111/j.1570-7458.1991.tb01553.x.

De Barro PJ, Trueman JW, Frohlich DR. 2005. Bemisia argentifolii is a race of $B$. tabaci (Hemiptera: Aleyrodidae): the molecular genetic differentiation of $B$. tabaci populations around the world. Bulletin of Entomological Research 95: 193-203.doi:https://doi.org/10.1079/BER2004351.

Flint HM, NJ Parks. 1990. Infestation of germplasm lines and cultivars of cotton in Arizona by whitefly numphs (Homoptera: Aleyrodidae). Journal of Entomological Science 25:22232229. doi: https://doi.org/10.18474/0749-800425.2.223.

Ginting BB. 1996. Biologi dan Statistik Demografi Maruca testulalis Geyer (Lepidoptera: Pyralidae) pada Bunga dan Polong Kacang Panjang. Tesis. Bogor: Institut Pertanian Bogor.

Harris KF, Smith OP, Duffus JE. 2001. Virus-insectplant interactions. San Diego: Academic Press.

Hidayat P, Aidawati N, Hidayat SH, Sartiami D. 2008. Tanaman indikator dan teknik RAPDPCR untuk penentuan biotipe Bemisia tabaci Gennadius (Hemiptera: Aleyrodidae). Jurnal HPT Tropika 8:1-7.

Horowitz A, Weintraub PG, Ishaaya I. 1998. Status of pesticide resistance in arthropod pests in Israel. Phytoparasitica 26:231-240. doi: https:// doi.org/10.1007/BF02981438.

Kalshoven LGE, Vecht JVD. 1950. De Plagen Van De Cultuurgewassen in Indonesie [dalam bahasa Belanda]. Deel 1. Bandung: NV Uitgeverij W. Van Hoeve.

Legg J, French R, Rogan D, Okao-Okuja G, Brown JK. 2002. A distinct Bemisia tabaci (Gennadius)
(Hemiptera: Sternorrhyncha: Aleyrodidae) genotype cluster is associated with the epidemic of severe cassava mosaic virus disease in Uganda. Molecular Ecology 11:1219-1229. doi: https:// doi.org/10.1046/j.1365-294X.2002.01514.x

Lima L, Návia D, Inglis P, De Oliveira M. 2000. Survey of Bemisia tabaci (Gennadius) (Hemiptera: Aleyrodidae) biotypes in Brazil using RAPD markers. Genetics and Molecular Biology 23:781-785. doi: https://doi.org/10.1590/S141547572000000400012.

McCollum T, Stoffella P, Powell C, Cantliffe D, HanifKhan. 2004. Effects of silverleaf whitefly feeding on tomato fruit ripening. Postharvest Biology and Technology. 31:183-190. doi: https://doi. org/10.1016/j.postharvbio.2003.09.001.

Naranjo SE, Ellsworth PC. 2005. Mortality dynamics and population regulation in Bemisia tabaci. Entomologia Experimentalis et Applicata. 116: 93-108. doi: https://doi.org/10.1111/j.15707458.2005.00297.x.

Oka IN. 1995. Pengendalian Hama Terpadu dan Implementasinya di Indonesia. Yogyakarta: Gadjah Mada University Press.

Oliveira M, Henneberry T, Anderson P. 2001. History, current status, and collaborative research projects for Bemisia tabaci. Crop Protection 20:709-723. doi: https://doi.org/10.1016/S0261-2194(01)001089.

Price PW. 1984. Insect Ecology (2nd ed). New York: John Wiley.

Qiu B, Chen Y, Liu L, Peng W, Li X, Ahmed M, Mathur V, Du Y, Ren S. 2009. Identification of three major Bemisia tabaci biotypes in China based on morphological and DNA polymorphisms. Natural Science 19:713-718. doi: https://doi.org/10.1016/j.pnsc.2008.08.013.

Subagyo VNO, Hidayat P. 2014. Statistik demografi kutukebul Bemisia tabaci (Gennadius) (Hemiptera: Aleyrodidae) pada tanaman cabai dan gulma babadotan pada suhu $25{ }^{\circ} \mathrm{C}$ dan 29 ${ }^{\circ} \mathrm{C}$. Jurnal Entomologi Indonesia 11:11-18. doi: https://doi.org/10.5994/jei.11.1.11.

Sudiono. 2003. Deteksi symtomolgy dan teknik PCR virus gemini asal tanaman tomat. Jurnal Agritek 11:537-544

van de Ven WT, LeVesque CS, Perring TM, Walling LL. 2000. Local and systemic changes in squash gene expression in response to silverleaf whitefly feeding. The Plant Cell 12:1409-1423. doi: https://doi.org/10.1105/tpc.12.8.1409.

Wang K, Tsai JH. 1996. Temperature effect on develompent and reproduction of silverleaf 
whitefly (Homoptera: Aleyrodidae). Annals of the Entomological Society of America 89:375384. doi: https://doi.org/10.1093/aesa/89.3.375.

Zang LS, Liu SS. 2007. A comparative study on mating behaviour between the $\mathrm{B}$ biotype and a non-B biotype of Bemisia tabaci (Hemiptera: Aleyrodidae) from Zhejiang, China. Journal Insect Behaviour 20:157. doi: https://doi. org/10.1007/s10905-006-9066-8.

Zang LS, Chen WQ, Liu SS. 2006. Comparison of performance on different host plants between the $\mathrm{B}$ biotype and a non-B biotype of Bemisia tabaci from Zhejiang, China. Entomologia Experimentalis et Applicata 121:221-227. doi: https://doi.org/10.1111/j.15708703.2006.00482.x.

Zeng F, Pederson G, Ellsbury M, Davis F. 199. Demographic statistics for the pea aphid (Homoptera: Aphididae) on resistant and susceptible red clovers. Journal of Economic Entomology 86:1852-1856. doi: https://doi. org/10.1093/jee/86.6.1852. 